\title{
STUDIES OF THE ROLE OF THE LIVER IN HUMAN CARBOHY- DRATE METABOLISM BY THE VENOUS CATHETER TECHNIC. II. PATIENTS WITH DIABETIC KETOSIS, BEFORE AND AFTER THE ADMINISTRATION OF INSULIN 1,2
}

\author{
By PHILIP K. BONDY, WALTER LYON BLOOM, VIRGINIA S. WHITNER \\ AND BETTY W. FARRAR
}

\author{
(From the Departments of Medicine and Biochemistry, Emory University School of Medicine, \\ and Grady Memorial Hospital, Atlanta, Ga.)
}

(Received for publication April 4, 1949)

The recent development of methods for the estimation of the blood flow and metabolism of the liver in man has made it possible to investigate the role of this organ in the normal and deranged metabolic processes of the human being. Previous studies have been concerned with the role of the liver in the carbohydrate metabolism of the normal human being (1). Similar investigations of patients with decompensated diabetic ketosis are reported in the present paper.

\section{METHODS}

Hepatic venous blood was obtained by a catheter passed through the right antecubital vein into a right hepatic vein. Blood was drawn from a Cournand needle lying in the femoral artery. The hepatic blood flow was estimated by the bromsulfalein extraction method of Bradley et al. (2). The technics of analysis have been discussed previously (1). In addition to studies of glucose and urea, ketone bodies were determined by the method of Weichselbaum and Somogyi (3). Throughout this paper, ketone bodies are expressed as the sum of acetone plus acetoacetic acid plus beta-hydroxybutyric acid (i.e., total ketone bodies). The standard errors of the various technics in our laboratory have been as follows: Glucose, $\pm 1.0 \mathrm{mg}$. per $100 \mathrm{ml}$. at a level of $100 \mathrm{mg} . / 100 \mathrm{ml}$; urea, $\pm 0.1 \mathrm{mg}$. per $100 \mathrm{ml}$. at a level of $30 \mathrm{mg} . / 100 \mathrm{ml}$; ketone bodies, $\pm 8.2 \mathrm{mg}$. per $100 \mathrm{ml}$. at a level of 100 mg./100 ml.

After several pretreatment observation periods, insulin was injected intravenously. In one case, an infusion was given, at a rate of 1 unit per minute. All other patients received 25 or 50 units every 30 minutes. All insulin used was Lilly "regular" insulin. Samples were collected simultaneously from the femoral artery and the hepatic vein at 15 minute intervals. No glucose was adminis-

1 Presented at the meeting of the American Society for Clinical Investigation, May 3, 1948, Atlantic City, New Jersey.

2 Part of the data presented in this paper have previously been published in abstract form (J. Clin. Invest., 1948, 27, 526). tered during the test. All patients had been fasting for at least 18 hours before the beginning of the observations. An accurate voided urine was collected for the 180 minute period of the experiment, and analyzed for glucose and ketone bodies.

\section{CLINICAL MATERIAL}

Five patients with diabetes mellitus were studied. These patients had been well controlled on insulin and a diet containing more than 150 grams of carbohydrate prior to the study, but had received no insulin for periods of 36 to 72 hours before the investigation was begun. No disease other than diabetes was evident, and none of the subjects were obese. Urine tests for ketone bodies were positive in all patients at the time the observations were started.

\section{CALCULATIONS}

The arterio-hepatic venous difference (A-HV) was obtained by subtracting the hepatic venous concentration from the arterial concentration. A positive value for this difference indicates that the splanchnic system was retaining the substance in question. By multiplying A-HV by the estimated hepatic blood flow (EHBF), the total splanchnic balance could be obtained. The relationship of this value to the hepatic balance is discussed below.

In the case of the ketone bodies, the large standard error of the method made it impossible to determine the value of $\mathrm{A}-\mathrm{HV}$ with confidence in a single observation. The mean value of $\mathrm{A}-\mathrm{HV}$ for the entire period was estimated by plotting graphically the arterial and hepatic venous concentrations against time, and integrating the difference with a polar planimeter. It was thus possible to obtain the mean difference of several estimations.

The rate of formation of glucose precursors from protein was estimated from the rate of urea production, assuming that the synthesis of 1 gram of urea releases 1.4 grams of glucose. The justification for this assumption has been discussed previously (1).

The rate of peripheral utilization of glucose and ketone bodies was calculated by subtracting the urinary excretion from the hepatic output. The caloric equivalents of these substances have been estimated by multiplying the value for glucose by 4.0 and for ketone bodies by 5.0 calories per gram. This has been compared with the 
"normal" basal metabolic requirement obtained from the tables of Aub and DuBois.

\section{RESULTS}

Hepatic blood flow: The mean hepatic blood flow appeared to be slightly higher than normal (Table I); however the difference was not significant chiefly because of the wide scatter of the values in the diabetic patients. Inspection of the table, however, indicates that the estimated hepatic blood flow varies directly with the total arterial ketone level. The correlation coefficient of this relationship is 0.86 , and the value of $p^{3}$ less than 0.01 . There was no significant relationship between the hepatic blood flow and the carbon dioxide combining power (Figure 1).

Hepatic glucose output in diabetic ketosis: The mean rate of glucose release by the splanchnic system in this group of patients was $6.9 \pm 1.73$ $\mathrm{mg} . / \mathrm{kg} . / \mathrm{min}$. (Table I). This may be compared

3 P from Fisher's tables. A significant value is considered to be one less than 0.02. All calculations were based on the technics for evaluation of small samples.

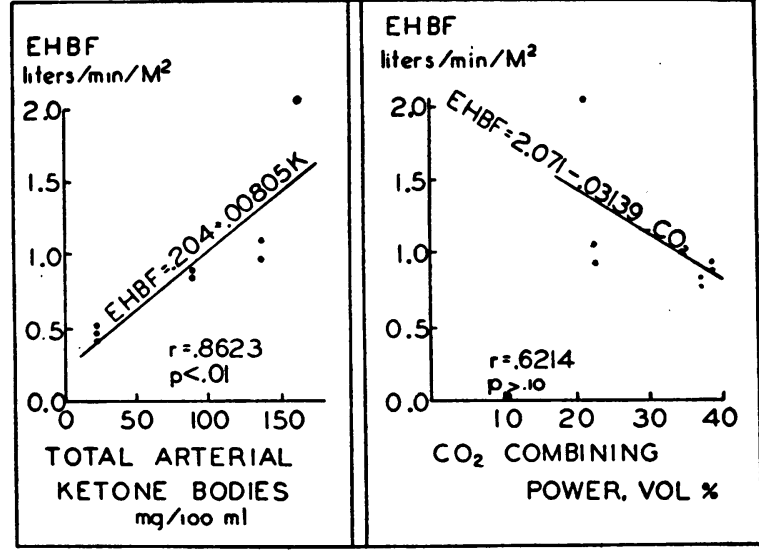

Fig. 1. Relationship of Hepatic Blood Flow to Arterial Ketone Body Concentration (Left) and Carbon Dioxide Combining Power (Right)

with the value of $3.4 \pm 0.7 \mathrm{mg} . / \mathrm{kg} . / \mathrm{min}$. in a group of normal individuals (1). The difference is significant ( $\mathrm{P}$ less than 0.02 ).

It was possible to calculate the amount of glucose lost in the urine of three of the patients. In Table I it may be seen that in all cases the hepatic

TABLE I

Glucose, urea and ketone body production by the liver in diabetic ketosis

\begin{tabular}{|c|c|c|c|c|c|c|c|c|c|c|c|c|c|c|}
\hline Patient & $\begin{array}{l}\text { Age } \\
\text { Sex }\end{array}$ & $\begin{array}{l}\text { Area } \\
M^{2} \\
W_{t} \\
k g .\end{array}$ & EHBF & $\left|\begin{array}{c}\mathrm{CO}_{2} \\
\text { comb. } \\
\text { power }\end{array}\right|$ & $\begin{array}{c}\text { Arterial } \\
\text { ketone } \\
\text { bodies }\end{array}$ & $\begin{array}{l}\text { Glucose } \\
\text { output }\end{array}$ & $\begin{array}{c}\text { Urea } \\
\text { output }\end{array}$ & $\begin{array}{l}\text { Glucose } \\
\text { from } \\
\text { protein }\end{array}$ & $\begin{array}{c}\text { Ketone } \\
\text { body } \\
\text { output }\end{array}$ & $\underset{\text { BMR }}{\text { Normal }}$ & $\begin{array}{l}\text { Glucose } \\
\text { calories }\end{array}$ & $\begin{array}{c}\text { Portion } \\
\text { of normal } \\
\text { from } \\
\text { BMR } \\
\text { glucose }\end{array}$ & $\begin{array}{l}\text { Ketone } \\
\text { calories }\end{array}$ & $\begin{array}{c}\text { Portion } \\
\text { of normal } \\
\text { BMR } \\
\text { from } \\
\text { ketone } \\
\text { bodies }\end{array}$ \\
\hline J. L. G. & $\begin{array}{l}15 \\
M\end{array}$ & $\begin{array}{c}1.35 \\
38.5\end{array}$ & $\begin{array}{c}\text { ml./. } \\
\text { min./ } \\
M^{2} \\
930 \\
900\end{array}$ & \begin{tabular}{|c|} 
ool. \\
per \\
cent \\
38.5
\end{tabular} & $\begin{array}{c}m g . / \\
100 \mathrm{ml}\end{array}$ & $\begin{array}{c}\text { mg./ } \\
\text { min./ } \\
\text { kg. } \\
8.1\end{array}$ & $\begin{array}{c}\text { mg./ } \\
\text { min./ } \\
\text { kg. } \\
2.70\end{array}$ & $\begin{array}{c}\text { per cent } \\
\text { of total } \\
\text { glucose } \\
42.5\end{array}$ & $\underset{\substack{\text { mg.j./ } \\
\text { kg./ }}}{ }$ & $\begin{array}{c}\text { cal.! } \\
\text { min. } \\
M^{2} \\
.766\end{array}$ & $\begin{array}{c}\text { per } \\
\text { min. } \\
M^{2}+ \\
.926\end{array}$ & $\begin{array}{c}\text { per cent } \\
121\end{array}$ & $\underset{M^{2}+}{\operatorname{per}}$ & per cent \\
\hline J.P. & $\begin{array}{l}21 \\
F\end{array}$ & $\begin{array}{c}1.53 \\
55.0\end{array}$ & 2040 & 21.5 & 162.0 & 13.1 & 2.70 & 29.2 & & .616 & 1.889 & 306 & & \\
\hline W. B. & $\begin{array}{l}16 \\
M\end{array}$ & $\begin{array}{r}1.39 \\
43.4\end{array}$ & $\begin{array}{l}894 \\
842\end{array}$ & 37.2 & 90.6 & 3.8 & 0.32 & 11.8 & 3.1 & .743 & .311 & 42 & .479 & 58 \\
\hline J. W. & $\begin{array}{l}51 \\
M\end{array}$ & $\begin{array}{l}1.72 \\
67.0\end{array}$ & $\begin{array}{r}956 \\
1095\end{array}$ & 22.5 & 137.7 & 4.6 & 0.51 & 8.2 & 4.0 & .623 & .479 & 77 & .779 & 118 \\
\hline J. W. C. & $\begin{array}{l}24 \\
\mathrm{M}\end{array}$ & $\begin{array}{l}1.75 \\
61.2\end{array}$ & $\begin{array}{l}526 \\
430 \\
482\end{array}$ & & 27.1 & 4.7 & 0.52 & 14.1 & 0.12 & .658 & .444 & 67 & .016 & 2 \\
\hline $\begin{array}{l}\text { Mean } \\
\text { St. error }\end{array}$ & & & $\begin{array}{l}910 \\
145\end{array}$ & & & $\begin{array}{l}6.9 \\
1.73\end{array}$ & $\begin{array}{l}1.35 \\
0.55\end{array}$ & $\begin{array}{r}21.2 \\
6.4\end{array}$ & & & $\begin{array}{l}.810 \\
.289\end{array}$ & & & \\
\hline $\begin{array}{l}\text { Normal } \\
\text { mean* } \\
\text { St. error }\end{array}$ & & & $\begin{array}{r}851 \\
71\end{array}$ & & & $\begin{array}{l}3.5 \\
0.70\end{array}$ & $\begin{array}{l}0.21 \\
0.05\end{array}$ & $\begin{array}{l}7.3 \\
1.0\end{array}$ & & & $\begin{array}{l}.459 \\
.094\end{array}$ & & & \\
\hline $\mathbf{p}$ & & & $>0.50$ & & & $<0.02$ & $<0.02$ & $<0.02$ & & & $>0.10$ & & & \\
\hline
\end{tabular}

* From previously reported normal human subjects (1).

$\dagger$ Total hepatic output, less loss in urine. This is equivalent to peripheral utilization. 
output was sufficient to account for the entire urinary glucose loss, and also to supply from $42 \%$ to $77 \%$ of the normal basal energy requirement.

Urea production in diabetic ketosis: The rate of formation of urea in the five diabetic patients averaged $1.35 \pm .55 \mathrm{mg} . / \mathrm{kg} . / \mathrm{min}$. as compared with $0.21 \pm 0.05 \mathrm{mg} . / \mathrm{kg} . / \mathrm{min}$. in the normal human being (1), a significant difference.

The increased rate of urea formation reflects an increased rate of protein catabolism, which contributes to the glucose produced by the liver. The calculated amount of glucose produced from protein in the diabetics ranged from $8.2 \%$ to $42 \%$ of the total hepatic glucose output, with a mean of $21.2 \pm 6.4 \%$. In normal fasting human beings, the mean conversion percentage was $7.3 \pm 1.0 \%$
(1). The difference is significant. No relationship could be established between the rate of protein breakdown and the hepatic blood flow, the arterial ketone body level, the arterial glucose level or the carbon dioxide combining power.

Hepatic ketone body production in diabetic ketosis: The output of ketone bodies by the splanchnic system varied from 0.12 to $4.0 \mathrm{mg} . / \mathrm{kg}$./ min. After subtracting the urinary ketone body loss, these substances were found to supply a caloric equivalent to the peripheral tissues of from $2 \%$ to $118 \%$ of the calculated total basal metabolic requirement (Table I).

The effect of insulin on the carbohydrate metabolism in diabetic ketosis: The protocols of the five patients during treatment are shown in Table

TABLE II

Effect of insulin on the splanchnic glucose balance in decompensated diabetic patients

\begin{tabular}{|c|c|c|c|c|c|c|c|c|c|c|c|c|c|c|c|c|}
\hline \multirow{2}{*}{ Patient } & \multicolumn{4}{|c|}{ Pretreatment } & \multicolumn{4}{|c|}{15 Minutes } & \multicolumn{4}{|c|}{30 Minutes } & \multicolumn{4}{|c|}{45 Minutes } \\
\hline & $\mathbf{A}$ & HV & ЕНBF & Balance & A & HV & EHBF & Balance & $\mathbf{A}$ & HV & ЕНBF & Balance & A & HV & EHBF & Balance \\
\hline J. L. G. & $\begin{array}{c}\mathrm{mg} . / \\
100 \mathrm{ml} . \\
313 \\
285 \\
310\end{array}$ & $\begin{array}{c}m g . / \\
100 \mathrm{ml} . \\
330 \\
331 \\
322\end{array}$ & $\begin{array}{l}\text { ml./ } \\
\text { min. } \\
1255 \\
1255 \\
1215\end{array}$ & $\begin{array}{c}\text { mg./ } \\
\text { min. } \\
-219 \\
-576 \\
-148 *\end{array}$ & $\begin{array}{c}m g . / \\
100 \mathrm{ml} \text {. } \\
248\end{array}$ & $\begin{array}{c}m g . / \\
100 \mathrm{ml} . \\
277\end{array}$ & $\begin{array}{l}\text { ml./ } \\
\text { min. } \\
1215\end{array}$ & $\begin{array}{c}\text { mg./ } \\
\text { min. } \\
-474\end{array}$ & $\begin{array}{c}m g . / \\
100 \mathrm{ml} . \\
220\end{array}$ & $\begin{array}{c}m g . / \\
100 \mathrm{ml} \text {. } \\
245\end{array}$ & $\begin{array}{l}\text { ml./ } \\
\text { min. } \\
1340\end{array}$ & $\begin{array}{l}\text { mg. } \\
\text { min. } \\
-335\end{array}$ & $\begin{array}{c}m g . / \\
100 \mathrm{ml} \text {. } \\
202\end{array}$ & $\begin{array}{c}m g . / \\
100 \mathrm{ml} . \\
218\end{array}$ & $\begin{array}{l}\text { ml./ } \\
\text { min. } \\
1132\end{array}$ & $\begin{array}{c}\text { mg./ } \\
\text { min. } \\
-182\end{array}$ \\
\hline J. P. & 436 & 466 & 3120 & $-718 t$ & 424 & 448 & 1865 & -485 & 390 & 420 & 1470 & $-442 \dagger$ & 364 & 367 & 1222 & -37 \\
\hline W. B. & 241 & 255 & 1170 & $-164 \dagger$ & 239 & 242 & 1292 & -40 & 212 & 224 & 1274 & $-153 \dagger$ & 186 & 202 & 1200 & -1928 \\
\hline J. W. & $\begin{array}{l}610 \\
651 \\
626\end{array}$ & $\begin{array}{l}646 \\
630 \\
652\end{array}$ & $\begin{array}{l}1640 \\
1640 \\
1885\end{array}$ & $\begin{array}{l}-591 \\
+163 \\
-490 \dagger\end{array}$ & 572 & 628 & 1950 & -1092 & 550 & 603 & 2820 & $-1495 \dagger$ & 466 & 487 & 2184 & -458 \\
\hline J. W. C. & $\begin{array}{l}416 \\
450\end{array}$ & $\begin{array}{l}432 \\
474\end{array}$ & $\begin{array}{l}1612 \\
1318\end{array}$ & $\begin{array}{l}-258 \\
-317 \dagger\end{array}$ & 408 & 412 & 1205 & -48 & 362 & 357 & 1178 & $+59 \ddagger$ & 310 & 313 & 1224 & -37 \\
\hline
\end{tabular}

TABLE II, Continued

\begin{tabular}{|c|c|c|c|c|c|c|c|c|c|c|c|c|}
\hline \multirow{2}{*}{ Patient } & \multicolumn{4}{|c|}{60 Minutes } & \multicolumn{4}{|c|}{75 Minutes } & \multicolumn{4}{|c|}{90 Minutes } \\
\hline & A & HV & EHBF & Balance & A & $\mathrm{HV}$ & EHBF & Balance & $\mathbf{A}$ & HV & EHBF & Balance \\
\hline J. L. G. & $\begin{array}{c}m g . / \\
100 \mathrm{ml} . \\
196\end{array}$ & $\begin{array}{c}\mathrm{mg} . / \\
100 \mathrm{ml} . \\
183\end{array}$ & $\begin{array}{l}\text { ml./ } \\
\text { min. } \\
2430\end{array}$ & $\begin{array}{c}\text { mg.l } \\
\text { min. } \\
-327\end{array}$ & $\begin{array}{c}m g . / \\
100 \mathrm{ml} . \\
158\end{array}$ & $\begin{array}{c}m g_{. \prime}^{\prime} \\
100 \mathrm{ml} . \\
165\end{array}$ & $\begin{array}{l}\text { ml./ } \\
\text { min. } \\
2430\end{array}$ & $\begin{array}{c}m g . / \min \\
-170\end{array}$ & $\begin{array}{c}m g . / \\
100 \mathrm{ml}\end{array}$ & $\begin{array}{c}m g . / \\
100 \mathrm{ml} . \\
-\end{array}$ & $\begin{array}{l}\text { ml./ } \\
\text { min. } \\
-\end{array}$ & $\begin{array}{c}\text { mg./ } \\
\text { min. } \\
-\end{array}$ \\
\hline J. P. & 342 & 340 & 1251 & +25 & 332 & 329 & 1251 & +38 & 324 & 291 & 1251 & +413 \\
\hline W. B. & 164 & 164 & 1920 & 0 & 142 & 147 & 1920 & -96 & 141 & 131 & 1920 & +192 \\
\hline J. W. & 483 & 476 & 1730 & $+121 \dagger$ & 491 & 484 & 2322 & +163 & 402 & 393 & 2322 & +209 \\
\hline J. W. C. & 282 & 265 & 1278 & $+215 t$ & 248 & 243 & 1467 & +74 & 227 & 217 & 1467 & +147 \\
\hline
\end{tabular}

* After this observation, a clysis of insulin, $1 \mathrm{unit} /$ minute was given intravenously.

$\dagger$ After this observation, 50 units of insulin were given intravenously.

I After this observation, 25 units of insulin were given intravenously.

$\$$ At this time, the patient received $50 \mathrm{ml}$. of water by mouth. 
TABLE III

Arterial, hepatic venous and arterio-venous differences of urea following treatment of diabetic ketosis with insulin (mg./100 ml.)

\begin{tabular}{|c|c|c|c|c|c|c|c|c|c|c|c|c|c|c|c|c|c|c|c|c|c|}
\hline \multirow[t]{2}{*}{ Patient } & \multicolumn{3}{|c|}{ Pretreatment } & \multicolumn{3}{|c|}{15 Minutes } & \multicolumn{3}{|c|}{30 Minutes } & \multicolumn{3}{|c|}{45 Minutes } & \multicolumn{3}{|c|}{60 Minutes } & \multicolumn{3}{|c|}{75 Minutes } & \multicolumn{3}{|c|}{90 Minutes } \\
\hline & A & HV & $A-\overline{H V}$ & $\mathbf{A}$ & HV & $\mathrm{A}_{\mathrm{HV}}$ & A & HV & $A \overline{H V}$ & A & HV & $A_{\overline{H V}}$ & A & $\mathrm{HV}$ & $A_{\overline{H V}}$ & A & HV & $\mathrm{A}_{\mathrm{HV}}$ & A & HV & $A_{\overline{H V}}$ \\
\hline J. L. G. & $\begin{array}{l}40.4 \\
30.0 \\
38.0\end{array}$ & $\begin{array}{l}43.1 \\
38.6 \\
35.4\end{array}$ & $\begin{array}{l}-2.7 \\
-8.6 \\
-2.6^{*}\end{array}$ & 33.9 & 35.8 & -1.9 & 32.9 & 33.2 & -0.3 & 32.3 & 31.0 & +1.3 & 30.8 & 29.1 & +1.7 & 29.3 & 27.9 & +2.4 & - & - & - \\
\hline J. P. & 44.8 & 49.6 & $-4.8 \dagger$ & 45.5 & 47.6 & -2.1 & 44.8 & 50.0 & $-5.2 \dagger$ & 44.5 & 47.2 & -2.7 & 44.6 & 47.3 & -2.7 & 40.8 & 45.2 & -4.4 & 44.8 & 42.8 & +2.0 \\
\hline W. B. & 34.1 & 35.2 & $-1.1 \dagger$ & 30.8 & 32.5 & -1.7 & 28.9 & 31.6 & $-2.7 \dagger$ & 29.3 & 31.5 & -2.28 & 30.5 & 30.3 & -0.2 & 29.3 & 29.7 & -0.4 & 28.9 & 28.1 & +0.8 \\
\hline J. W. & $\begin{array}{l}88.6 \\
87.8 \\
86.6\end{array}$ & \begin{tabular}{|l|}
89.4 \\
88.4 \\
88.4
\end{tabular} & $\begin{array}{l}-0.8 \\
-0.6 \\
-1.8 \dagger\end{array}$ & 87.0 & 88.4 & -1.4 & 86.6 & 86.2 & $+0.4 \dagger$ & 89.8 & 87.8 & +2.0 & 87.2 & 85.4 & $+1.8 \dagger$ & 85.6 & 84.0 & +1.6 & 81.6 & 86.5 & -4.0 \\
\hline J. W. C. & $\begin{array}{l}36.2 \\
37.4\end{array}$ & $\begin{array}{l}38.2 \\
37.8\end{array}$ & $\begin{array}{l}-2.0 \\
-0.4 \dagger\end{array}$ & 34.6 & 37.2 & -2.6 & 34.8 & 34.6 & $-0.2 \ddagger$ & 33.4 & 33.4 & 0.0 & 32.6 & 33.2 & $-0.6 \ddagger$ & 30.2 & 31.8 & -1.6 & 29.8 & 30.8 & -1.0 \\
\hline
\end{tabular}

* After this observation, a clysis of insulin, 1 unit/minute, was given intravenously.

$\dagger$ After this observation, 50 units of insulin were given intravenously.

$\ddagger$ After this observation, 25 units of insulin were given intravenously.

$\S$ At this time, the patient received $50 \mathrm{ml}$. of water by mouth.

II. Within 15 minutes after the first injection of insulin a decrease in the arterial glucose level occurred. The decline was maintained throughout the entire treatment period, except in the case of J. W., after 45 minutes, and W. B., after 75 minutes. In the latter case, no insulin had been administered for 45 minutes when the arterial concentration of glucose levelled off.

In all cases except one, the splanchnic glucose balance remained negative, i.e., the liver continued to pour out glucose into the circulation, until at least 45 minutes after the beginning of therapy. In the case of J. W. C., a temporary positive balance was established at 30 minutes. This patient had very mild ketosis, shown by a total arterial ketone body level of only $27 \mathrm{mg}$./100 $\mathrm{ml}$.

In two cases (W. B. and J. W.), there was a temporary increase in the rate of glucose production shortly after the institution of insulin therapy.

The effect of insulin on the ketone body metabolism in diabetic ketosis: The ketone body level in the blood fell during treatment with insulin. The inaccuracies of the analytical method used make it impossible to ascertain the role played by the liver in this decline.

The effect of insulin on the urea metabolism in diabetic ketosis: Before treatment, all patients had negative values for $\mathrm{A}-\mathrm{HV}$, indicating that the splanchnic system was adding urea to the blood. In each instance, as treatment progressed, at least one observation was made in which A-HV was positive (Table III). It was not possible to correlate this occurrence with the status of the glucose balance, although in two patients, the urea and glucose balance patterns were nearly parallel ( $\mathrm{J}$. L. G. and J. P.). The significance of this apparent retention of urea by the splanchnic system is discussed below.

\section{DISCUSSION}

The hepatic venous catheter technic permits one to estimate the metabolism of the entire splanchnic system. Since it is impossible at present to obtain portal blood from the intact human subject, it is not feasible to separate the activity of the liver from that of the extra-hepatic splanchnic organs. It is possible, however, to predict in some degree the direction and magnitude of the error which is introduced if one assumes that the splanchnic metabolism is equivalent to that of the liver.

It has previously been shown (1) that in the normal human subject, the error introduced by lack of data pertaining to portal glucose concentration is small under basal conditions. Because of the utilization of part of the glucose traversing the digestive organs and the spleen, there is a tendency to minimize the apparent amount of glucose contributed to the circulation by the liver. In the diabetic individual, however, the uptake of glucose by most tissues is reduced (4). This would decrease the magnitude of the error. In diabetic dogs, for example, the portal venous glucose concentration has been observed to be $3 \mathrm{mg} . / 100 \mathrm{ml}$. 
lower than the arterial, at an arterial concentration of $336 \mathrm{mg} . / 100 \mathrm{ml}$. (5). This small difference could not be observed by the methods used for the present study. For the uncontrolled diabetic patient, therefore, splanchnic and hepatic glucose balances are probably essentially the same.

After increasing the utilization of glucose, by the administration of insulin, the hepatic and splanchnic balances can no longer be considered equivalent. As in the case of the normal subject, however, the error will always tend to minimize the glucose contribution of the liver. No data are available from which the magnitude of this effect can be estimated. The terms "splanchnic" and "hepatic" may therefore be used interchangeably in speaking of the glucose metabolism of the untreated diabetic, but the results of observations by the liver catheter technic after the administration of insulin imust be considered only as reflections of the glucose metabolism of the entire splanchnic system.

The extra-hepatic splanchnic organs neither utilize nor produce urea. It is, however, impossible to estimate the amounts of urea which may be withdrawn from the blood and released into the intestinal tract in the bile, gastric, pancreatic and intestinal juices. This loss of urea into the gut may explain the apparent retention of urea by the splanchnic system in the treated diabetic patient. It should be noted, however, that the digestive juices contain urea in a concentration approximating that of the blood (6). The secretion of these juices would not, therefore, be expected to alter the concentration of urea in the blood traversing the splanchnic system.

The apparent splanchnic urea balance might also be altered by dilution of the blood passing through the gut, either by absorption of ingested water or by release of water formed by the oxidation of hydrogen-containing foodstuffs. The first source was eliminated by examining the patients in a post-absorptive state. In one instance, a patient received a drink of water by mistake during the procedure. A definite depression of the hepatic venous urea level occurred in the next specimen (Table III, W. B., 60 minutes).

Water of oxidation is not sufficient to produce a perceptible alteration of hepatic venous concentration. The splanchnic oxidation of $180 \mathrm{mg}$. of glucose per minute ( 0.72 calories, equivalent to about one-half of the basal metabolic requirement) would reduce the hepatic venous urea concentration by only about $0.1 \mathrm{mg} . / 100 \mathrm{ml}$., a difference within the error of the method of determination.

Although the quantitative relationships between the splanchnic balance and the hepatic balance of the substances studied is somewhat complicated, it should be emphasized that the chief cause of the alterations observed in the splanchnic balance is the activity of the liver.

The large error of the method for determining ketone bodies prevented the estimation of the small A-HV differences directly, and therefore no attempt was made to draw conclusions about the hepatic or splanchnic balances in short observations in the present study. Considerable conservatism should be exercised even with regard to the estimation of $\mathrm{A}-\mathrm{HV}$ by planimetric methods. The results obtained in this manner are probably of the right order of magnitude, but cannot be considered as reliable as the glucose or urea determinations.

In spite of the small number of observations, a significant direct correlation has been found between the hepatic blood flow and the arterial ketone body level. It is not possible to determine whether the elevated ketone body concentration causes the increased blood flow, or whether both reflect some more basic derangement. This observation is consistent with the findings of Howarth, McMichael and Sharpey-Schafer (7) that in severe diabetic acidosis the cardiac output is normal or increased, and the peripheral vascular resistance is diminished. It is possible that the enhanced hepatic blood flow merely reflects the reduced vascular resistance of the extra-hepatic components of the splanchnic system. In view of the increased liver oxygen requirement for carrying on deamination and ketone body formation, however, it seems probable that the augmented hepatic blood flow is of importance in supplying oxygen needed for the pathologic metabolic activities.

The small number of observations probably accounts for the fact that the correlation between hepatic blood flow and the carbon dioxide combining power was not significant.

Calculation of the glucose balance showed a higher rate of release from the liver of the untreated diabetic patient than the normal human being. This finding is somewhat more definite 
than the findings of Crandall and Lipscomb (8) in dogs. These authors found that pancreatectomized dogs released more glucose from their livers than did normal dogs, but the increase was not significant statistically. The apparent difference between the results in humans and dogs may be caused in part by the very high value of EHBF in patient $\mathrm{J}$. P.

It has frequently been shown that the rate of peripheral glucose utilization is increased when the blood glucose level is raised (9). In spite of the high dextrose concentrations found in the diabetic patients, however, carbohydrate utilization was not increased as compared to normal subjects previously studied by the same technic (1). These data, therefore, indicate an increased hepatic glucose output and a relative under-utilization of carbohydrate in the decompensated human diabetic patient. It seems probable that the increased arterial glucose level, made possible in part by the high rate of glucose release by the liver, permits the diabetic tissues to utilize normal quantities of glucose.

It has been shown in diabetic human beings (10) and in animals made diabetic by pancreatectomy (11) or by alloxan (12) that the liver glycogen is usually decreased when the subjects are in severe ketosis. The increased glucose output could not, therefore, be explained merely on the basis of increased glycogenolysis. It can, however, be accounted for almost entirely by increased proteolysis. The finding of increased urea production and protein breakdown by the decompensated diabetic liver agrees with the findings of others by means of balance studies in man (13) and in animals (14). The increased formation of glucose accompanied by an increased rate of urea formation is consistent with Stetten's observations (15) that in alloxan-diabetic rats or rabbits there is a normal or increased rate of glycogen formation from substances smaller than hexose. In our patients, it appears that an increased availability of such glucose precursors occurred as a result of the deamination of amino acids in the liver. The resulting nitrogen-free fragments of amino acids appear to have been incorporated into carbohydrate and to account in large part for the increased glucose production.

Ketone bodies were also found to contribute to the metabolic pattern of the decompensated dia- betic patient. As might have been anticipated, the percentage of the metabolic needs supplied by ketone bodies was proportional to the degree of ketosis.

The metabolic pattern presented in Table $I$ is expressed in terms of percentage of normal basal metabolic rate supplied by glucose and by ketone bodies. In each case, except that of J. W. C., the mildest case, these percentages add up to more than $100 \%$. This is probably chiefly because patients in diabetic ketosis are not in a basal condition. It should also be emphasized that the fact that a material is being retained by the tissues does not necessarily mean that it is immediately being used for the production of energy. It is not possible by the technics used to estimate the importance of substances previously stored as fat, muscle glycogen, etc., in supplying the metabolic requirements of the organism. Moreover, the actual metabolic rate was not determined in these patients at the time of observation. The percentages presented, therefore, do not reflect the portion of the actual metabolic needs supplied by each of the components.

Presumably, the glucose retention following the injection of insulin reflects the formation of glycogen by the liver, although an enhanced formation of fat in the liver and viscera probably also takes place. The effect of the extra-hepatic viscera, as mentioned above, is to cause an apparent increase in the retention of glucose by the splanchnic system. The delay in the retention of glucose by the splanchnic viscera is therefore shortened by the effect of the activity of the extra-hepatic splanchnic system. The apparent delay of one hour before glucose was retained by the splanchnic system therefore implies that an even longer time was necessary before the liver began to retain glucose. Direct observations of the liver glycogen of diabetic patients (10) have shown that after treatment with insulin the glycogen concentration increases slowly at first and accelerates as therapy proceeds. This is consistent with the observations in the present series of patients.

In two patients, there was actually a considerable increase in the rate of release of glucose by the liver after the administration of insulin. The presence of glycogenolytic substances in commercial insulin has recently been emphasized (16). The 
effect noted in these patients may have been due to the presence of this material in the insulin.

After the administration of insulin, there was a decrease in the rate of urea formation until all patients, at one time or another, had a positive splanchnic balance. As discussed above, some part of this retention of urea may have been artifact. In certain instances, however, the retention was of such magnitude that this effect seems insufficient to account for them (Table III, J. L. G., 45, 60, and 75 minutes; J. W., 45, 60, 75 minutes; J. P., 90 minutes). One is therefore tempted to consider the possibility that urea may have reentered the body economy of these patients. Schoenheimer (17) has shown that in normal fed rats $96 \%$ of orally administered nitrogen-labeled urea is recovered unchanged in the urine. Leifer et al. (18), however, have shown that up to $20 \%$ of the radioactivity of injected carbon-labeled urea may be recovered in the expired carbon dioxide within three hours. Certainly the period of recovery from diabetic acidosis should be one of the best times to see any anabolic activity of urea which is perceptible by ordinary chemical methods of study. The effect of insulin on protein metabolism, in any case, appears to be dramatic. The inhibition of hepatic urea formation occurs so early that it preceded or paralleled the carbohydrate effects in all cases. J. L. G., for example, had a positive splanchnic urea balance after 45 minutes of treatment, but did not begin to retain glucose even after 75 minutes.

\section{SUMMARY}

Five patients with uncontrolled diabetes mellitus have been studied by the liver catheterization technic. There was an increased rate of splanchnic glucose and urea production as compared with normal subjects. As the arterial ketone body concentration rose, the hepatic blood flow also increased. There was a normal rate of utilization of glucose in the peripheral tissues. Ketone bodies were also utilized.

After the administration of insulin, the arterial glucose level fell and the rate of splanchnic glucose production decreased. After latent periods of from 45 to more than 75 minutes, the splanchnic system began to retain glucose, presumably chiefly as glycogen. In two instances, there was a considerable temporary increase in hepatic glu- cose production immediately after the injection of insulin. This may have been due to the effect of the insulin glycogenolytic factor.

The rate of urea production was rapidly reduced by insulin. In all instances, the splanchnic system retained urea for one or more experimental periods while under the influence of insulin. This effect occurred at least as rapidly as the effects on carbohydrate metabolism.

\section{BIBLIOGRAPHY}

1. Bondy, P. K., James, D. F., and Farrar, B. W. Studies of the role of the liver in human carbohydrate metabolism by the venous catheter technic. I. Normal patients under fasting conditions and after the administration of glucose. J. Clin. Invest., 1949, 28, 238.

2. Bradley, S. E., Ingelfinger, F. J., Bradley, G. P., and Curry, J. J., The estimation of hepatic blood flow in man. J. Clin. Invest., 1945, 24, 890.

3. Weichselbaum, T. E., and Somogyi, M., A method for the determination of small amounts of ketone bodies. J. Biol. Chem., 1941, 140, 5.

4. Rabinowitch, I. M., Simultaneous determinations of arterial and venous blood sugars in diabetic individuals. British J. Exper. Path., 1927, 8, 76.

5. Crandall, L. A., Jr., Lipscomb, A., and Barker, S. B., Utilization of glucose and acetone bodies by gastrointestinal tract in fasting normal and diabetic dogs. Proc. Soc. Exper. Biol. \& Med., 1946, 63, 533.

6a. Rietti, C. T., Difusíon de la urea en diferentes liquidos del organismo. Rev. Soc. argent. de Biol., 1927, 3, 399.

b. Pendleton, W. R., and West, F. E., The passage of urea between the blood and the lumen of the small intestine. Am. J. Physiol., 1932, 101, 391.

c. Chabrol, E., Charonnat, R., Maximin, M., and Cottet, J., La sécrétion biliaire dans l'urémie expérimentale. Compte rend. Soc. de biol., 1933, 114, 464.

7. Howarth, S., McMichael, J., and Sharpey-Schafer, E. P., Low blood pressure in diabetic coma. Clin. Sc., 1948, 6, 247.

8. Crandall, L. A., Jr., and Lipscomb, A., Direct measurement of hepatic glucose production in experimental diabetes mellitus. Am. J. Physiol., 1947, 148, 312.

9. Somogyi, M., Studies of arteriovenous differences in blood sugar. I. Effect of alimentary hyperglycemia on the rate of extrahepatic glucose assimilation. J. Biol. Chem., 1948, 174, 189.

10. Bondy, P. K., Sheldon, W. H., and Evans, L. D., Changes in liver glycogen studied by the needle aspiration technic in patients with diabetic ketosis; with a method for the estimation of glycogen from histologic preparations. J. Clin. Invest., 1949, 28, 1216. 
11. Minkowski, O., Untersuchungen über den Diabetes Mellitus nach Exstirpation des Pankreas. Arch. f. exper. Path. u. Pharmakol., 1893, 31, 85.

12. Lackey, R. W., Bunde, C. A., Gill, A. J., and Harris, L. C., Glycogen in alloxan-treated rats. Proc. Soc. Exper. Biol. \& Med., 1944, 57, 191.

13. Atchley, D. W., Loeb, R. F., Richards, D. W., Jr., Benedict, E. M., and Driscoll, M. E., On diabetic acidosis. A detailed study of electrolyte balances following the withdrawal and reestablishment of insulin therapy. J. Clin. Invest., 1933, 12, 297.

14. von Falkenhausen, M. F., Untersuchungen über den Eiweißstoffwechsel beim Experimentellen Pan- kreasdiabetes. Arch. exper. Path. u. Pharmakol., 1925, 109, 249.

15. Stetten, DeW., Jr., The study of certain pathologic processes with the aid of isotopic hydrogen. New York State J. Med., 1947, 47, 1991.

16. Sutherland, E. W., and DeDuve, C., Origin and distribution of the hyperglycemic-glycogenolytic factor of the pancreas. J. Biol. Chem., 1948, 175, 663.

17. Schoenheimer, R., The Dynamic State of Body Constituents. Harvard University Press, Cambridge, Mass., 1942, p. 50.

18. Leifer, E., Roth, L. J., and Hempelmann, L. H., Metabolism of $\mathrm{C}^{14}$-labeled urea. Science, 1948, $108,748$. 